\title{
UPAYA PENINGKATKAN PRESTASI BELAJAR MATEMATIKA VOLUME PRISMA SEGI TIGA DAN TABUNG MELALUI MODEL PEMBELAJARAN MAKE A MATCH DI KELAS VI SDN 2 SUKOMULYO
}

\author{
Temu Rahayu \\ SD Negeri 2 Sukomulyo
}

\begin{abstract}
Abstrak
Penelitian tindakan kelas ini bertujuan untuk meningkatkan prestasi belajar siswa khususnya mata pelajaran Matematika materi volume prisma segi tiga dan volume tabung melalui model pembelajaran make a match. Penelitian tindakan kelas ini dilaksanakan di SDN 2 Sukomulyo Kecamatan Kaliwungu Selatan Kabupaten Kendal pada semester I, dengan subjek penelitian berjumlah 20 siswa terdiri 10 laki-laki dan 10 perempuan. Penelitian dilaksanakan dalam 2 siklus, tiap siklus dilaksanakan dua kali pertemuan dengan kegiatan perencanaan, tindakan, observasi, dan refleksi. Teknik pengumpulan data menggunakan tes untuk mengetahui prestasi belajar dan lembar observasi untuk mengetahui aktivitas siswa dan kemampuan guru dalam menggunakan model pembelajaran make a match. Analisis data menggunakan analisis deskriptif. Hasil penelitian menunjukkan bahwa pada siklus I sudah ada peningkatan dibanding pra siklus walau belum segnifikan yakni ada 13 siswa yang memperoleh nilai di atas 60 dari 20 siswa dengan ketuntasan. Selanjutnya pada siklus II ketuntasan mencapai $90 \%$ dan nilai rata-rata 76 pada siklus I nilai rata-rata 64,5. Dengan metode make a match ini siswa lebih enjoy karena bisa tanya jawab dengan teman, intinya dapat bermain sambil belajar.
\end{abstract}

Kata kunci : prestasi belajar matematika, model pembelajaran make a match.

\begin{abstract}
This classroom action research aims to improve student achievement in particular subjects Mathematics triangular prism volume of material and the volume of the tube through a learning model make a match. This classroom action research conducted in SDN 2 Sukomulyo District of South Kaliwungu Kendal in the first semester, with a total of 20 students study subjects comprised 10 males and 10 females. The experiment was conducted in two cycles, each cycle held two meetings with the activities of planning, action, observation, and reflection. Data collection technique used to determine learning achievement tests and observation sheets to determine the activities of the students and the teacher's ability to use the learning model make a match. The data analysis using descriptive analysis. The results showed that in the first cycle has been no increase compared to pre-cycle though not segnifikan that there are 13 students who scored in the top 60 of the 20 students with mastery. Furthermore, in the second cycle completeness reached $90 \%$ and the average value of 76 in the first cycle the average value of 64.5. With this method
\end{abstract}


students make a match more enjoy because it can be a question and answer with a friend, the point can play while learning.

Keywords : mathematics achievement, learning model make a match .

\section{A. Pendahuluan}

Mata pelajaran Matematika mempunyai peran penting dalam memajukan daya pikir manusia. Untuk menguasai dan mencipta teknologi di masa mendatang diperlukan penguasaan matematika yang kuat sejak dini. Matematika dapat mendidik siswa berpikir kritis, logis, sistimatis, dan kreatif. Kompetensi tersebut sangat diperlukan untuk masa mendatang agar dapat bertahan hidup, dalam keadaan yang selalu berubah, tidak pasti dan kompetitif matematika dan sains tidak bisa dipisahkan. Sebagai pengetahuan Matematika mempunyai ciri-ciri khusus antara lain abstrak, deduktif, herarkhis dan logis. Soejadi menyatakan bahwa keabstrakan Matematika objek dasarnya abstrak, yaitu fakta, konsep, operasi dan prinsip1. Ciri keabstrakan Matematika yang tidak sederhana menyebabkan Matematika tidak mudah dipelajari sehingga banyak anak yang "benci" dan "alergi" terhadap matematika.

Karena ilmu ini sangat penting maka guru perlu menjembatani agar matematika disukai anak atau tidak menjadikan alergi. Tantangan bagi pendidik untuk membuat jembatan yang aman dan nyaman. Banyak teori yang bisa dipakai dalam pembelajaran matematika. Teori Ausubel mengemukakan pentingnya pembelajaran bermakna, kegiatan belajar dibuat menarik, menantang, sehingga konsep mudah dipelajari, dingat dan tahan lama. Metode mengajar merupakan salah satu komponen yang harus ada dalam kegiatan pembelajaran. Pada dasarnya metode mengajar ini merupakan cara atau teknik yang digunakan guru dalam melakukan interaksi dengan siswa pada saat proses pembelajaran berlangsung.

Oleh karena penting dan dianggap sulit alokasi waktu mata pelajaran Matematika dalam struktur kurikulum Sekolah Dasar lebih banyak dibanding mata pelajaran yang lain, kecuali Bahasa Indonesia yaitu 1 dalam 5 jam minimal. Meskipun alokasi waktu Matematika mendapat jatah terbanyak, nilai yang dihasilkan lebih rendah dari mata pelajaran Bahasa Indonesia, IPA, IPS dan PKn. Hasil nilai UAN mata pelajaran Matematika dari tahun ke tahun rata-rata di bawah mata pelajaran Bahasa

${ }^{1}$ Soedjadi, R., Kiat Pendidikan Matematika di Indonesia (Konstatasi Keadaan Masa Kini Menuju Harapan Masa Depan, (Jakarta: Ditjen Dikti Depdikbud, 1999) 
Indonesia dan Ilmu Pengetahuan Alam. Di SD 2 Sukomulyo Kriteria Ketuntasan Minimal (KKM) kelas I - VI tidak berani mematok nilai di atas 60. Keadaan ini sangat memprihatinkan, kebanyakan siswa merasa sulit untuk berpikir, bosan sehingga kurang bersemangat bila pelajaran Matematika.

Di kelas VI SD 2 Sukomulyo, hasil tes formatif mata pelajaran Matematika mengenai penggunaan pengukuran volume belum mencapai hasil yang maksimal, yakni dari 20 siswa hanya 2 siswa yang memperoleh nilai 70 dengan rata-rata 53. Hal tersebut dikarenakan dalam proses pembelajaran siswa terlihat kurang aktif dan malas berpikir. Pertanyaan dari guru dijawab secara sembarangan, kadang tidak menjawab. Siswa terlihat pasif kurang memperhatikan.

Berdasarkan latar belakang tersebut maka rumusan masalah pada penelitian ini "apakah melalui strategi pembelajaran model make a match (mencari pasangan) dapat meningkatkan prestasi belajar matematika volume prisma segi tiga dan tabung di kelas VI SD 2 Sukomulyo kec. Kaliwungu Selatan kab. Kendal?" Adapun tujuan penelitian ini adalah untuk meningkatkan prestasi belajar matematika volume prisma segi tiga dan tabung dengan pembelajaran yang menyenangkan yaitu strategi pembelajaran make a match.

\section{B. Landasan Teori}

\section{Prestasi Belajar Matematika}

Winkel mengatakan bahwa prestasi belajar adalah suatu hasil usaha yang telah dicapai oleh siswa yang mengadakan suatu kegiatan belajar di sekolah dan usaha yang dapat menghasilkan perubahan pengetahuan, sikap dan tingkah laku. ${ }^{2}$ Hasil perubahan tersebut diwujudkan dengan nilai atau skor. Menurut Sunaryo, prestasi belajar adalah hasil perubahan kemampuan meliputi kemampuan kognitif, psikomotor dan afektif. ${ }^{3}$ Sedangkan menurut Hamalik prestasi belajar

2 Nasukha, Penggunaan Media Sempoa dalam Pembelajaran Matematika Siswa Kelas IV SD N Gondang I Kecamatan Nawangan Pacitan Tahun Pelajaran 2007/2008, Skripsi, (Universitas Sebelas Maret, 2008), hlm 18.

3 Rianarwati, Dwi, Penggunaan Media Gambar Dalam Pembelajaran Untuk Meningkatkan Prestasi Belajar Pengetahuan Sosial Kelas IV SD Mangun Baru Wates Kulon Progo, Skripsi, (UNY: Tidak diterbitkan. 2006), hlm 16. 
adalah hal-hal yang telah dicapai oleh seseorang setelah melakukan kegiatan. ${ }^{4}$

Menurut James (dalam Ruseffendi, dkk 1996: 27-28) matematika adalah ilmu tentang logika mengenai bentuk, susunan, besaran, dan konsep- konsep yang saling berhubungan satu sama lainnya dengan jumlah yang banyaknya terbagi ke dalam tiga bidang yaitu aljabar, analisis, dan geometri. Matematika adalah pola berpikir, pola mengorganisasikan pembuktian yang logis. Matematika adalah bahasa yang menggunakan istilah yang didefinisikan dengan cermat, jelas dan akurat representasinya dengan simbol dan padat.

Berdasarkan pengertian-pengertian yang dikemukakan di atas, dapat disimpulkan bahwa prestasi belajar matematika adalah hal-hal yang telah dicapai oleh seseorang setelah melakukan kegiatan yang mempelajari pola berfikir, pola pengorganisasian pembuktian yang logis, serta bahasa dan penelaahannya yang dibangun melalui proses penalaran deduktif.

\section{Model Pembelajaran Make A Match}

Model pembelajaran mencari pasangan (make a match) dikembangkan oleh Curran (1994). Salah satu keunggulan model ini adalah siswa dapat belajar suatu konsep sambil bermain dengan mencari pasangan dari jawaban soal yang sedang dikerjakan. Model ini dapat digunakan pada semua mata pelajaran dan untuk semua tingkatan usia anak didik. Model pembelajaran make a match sebenarnya bisa disebut sebagai teknik atau strategi pembelajaran. Sedangkan make a match sendiri termasuk salah satu teknik pembelajaran cooperative learning. Masih ada beberapa strategi pembelajaran aktif yang hampir sama misal index card match (mencocokkan kartu indeks), kemudian giving question and getting answers (memberi pertanyaan dan menerima jawaban) strategi sangat baik digunakan untuk mengulang materi pelajaran yang biasanya dilakukan 5 menit sebelum pelajaran selesai atau di akhir semester untuk mengingatkan kembali materi-materi yang pernah dipelajari. ${ }^{5}$

Langkah-langkah model pembelajaran make a match: (1) Guru menyiapkan beberapa kartu yang berisi konsep-konsep sederhana yang

4 Hamalik, Oemar, Proses Belajar Mengajar, (Jakarta: PT Bumi Aksara, 2009), hlm 4.

5 Zaini, Hisyam dkk., Strategi Pembelajaran Aktif, (Jogyakarta: PT Insan Madani Islamic Publisher, 2008), hlm 33. 
saling berpasangan untuk sisi muka dan sisi belakang dengan warna yang berbeda, (2) Masing-masing siswa mendapat sebuah kartu yang mempunyai dua sisi yang berbeda, (3) Siswa dipersilahkan membuka kartu dengan warna putih (misalnya), guru memberi waktu 1 menit untuk memikirkan jawabannya, (4) Siswa dipersilahkan untuk mencari pasangan dari kartunya, dengan cara setiap anak untuk memperlihatkan sisi kartu pada temannya. Misal pemegang kartu bertuliskan "22/7 x r x r x t" akan berpasangan dengan pemegang kartu bertuliskan "volume tabung", (5) Satu kartu bisa mendapat 2 atau 3 pasangan yang cocok, dan (6) Babak selanjutnya kartu bisa ditarik dulu dikocok dan dibagikan lagi.

\section{Penelitian yang Relevan}

Hasil penelitian yang ditunjukkan oleh Rosanto (2009) berjudul penelitian "Penerapan Model Make A Match Pada Mata Pelajaran IPS Tentang Keadaan Alam Indonesia Untuk Meningkatkan Hasil Belajar Siswa Kelas V SDN 02 Semanggi Kecamatan Jepon Kabupaten Blora“, dapat meningkatkan keaktifan siswa yang dibuktikan dengan rata-rata nilai siswa pada siklus I 70,83 dengan KKM 65 ketuntasan klasikal 66,66\%. Pada siklus II mengalami kenaikan dengan rata-rata 80 dengan ketuntasan $100 \%{ }^{6}$

Penelitian lain yang dilakukan oleh Rejeki (2009) tentang "Penerapan Pembelajaran Model Make A Match Pada Mata Pelajaran IPA Untuk Meningkatkan Hasil Belajar Siswa Kelas V SDN 02 Sengonwetan Semester 2 Th 2010/2011", menyimpulkan hasil analisis data keaktifan siswa pada kondisi awal 51\%. Pada siklus I mencapai 75\% dilanjutkan pada siklus II sebesar $85 \%$. Kesimpulan yang diambil peningkatan aktifitas siswa memberi dampak pada hasil belajar siswa . Hasil belajar yang tercatat kondisi awal 51\%, siklus I ketuntasan mencapai 75\% dan siklus II meningkat 85\%, dengan rata-rata kondisi awal 66, siklus I 78 dan siklus II rata-rata nilai kelas $88 .^{7}$

${ }^{6}$ Rosanto, Penerapan Model Make A Match Pada Mata Pelajaran IPS Tentang Keadaan Alam Indonesia Untuk Meningkatkan Hasil Belajar Siswa Kelas V SDN 02 Semanggi Kecamatan Jepon Kabupaten Blora, 2009, repository.library.uksw.edu/.../T1_292008231_BAB\%. Diunduh tanggal 21 September 2013.

7 Rejeki, Sri, Penerapan Pembelajaran Model Make A Match Pada Mata Pelajaran IPA Untuk Meningkatkan Hasil Belajar Siswa Kelas V SDN 02 Sengonwetan Semester 2 Th 2010/2011, 2009, Dalam repository.library. uksw.edu/./T1_292008013_Daftar. Diunduh 21 September 2013.

54 MAGISTRA - Volume 6 Nomor 2 Oktober 2015 
Merujuk pada penelitian-penelitian-penelitian tersebut maka peneliti mencoba menggunakan metode make a match guna meningkatkan prestasi belajar matematika volume prisma segi tiga dan tabung dalam pembelajaran matematika di kelas V SDN 2 Sukomulyo.

\section{Kerangka Berpikir}

Pembelajaran yang baik adalah yang dapat mengaktifkan semua siswa, baik aktif secara emosional, fisik, dan melibatkan lebih dari 2 indera. Siswa berpikir namun tidak terasa, karena bisa bertanya pada temannya untuk mencari pasangan kartunya. Untuk itu peneliti berusaha untuk mengaktifkan siswa dengan mencari pasangan (make a match). Siswa akan mendapat kartu soal / kartu jawaban. Siswa sambil berdiskusi dengan temannya memikirkan jawaban dari kartu soal yang dipegangnya lalu mencari pasangan dari kartu jawaban soal kartunya. Setelah ketemu ia akan maju berdampingan dengan pasangan

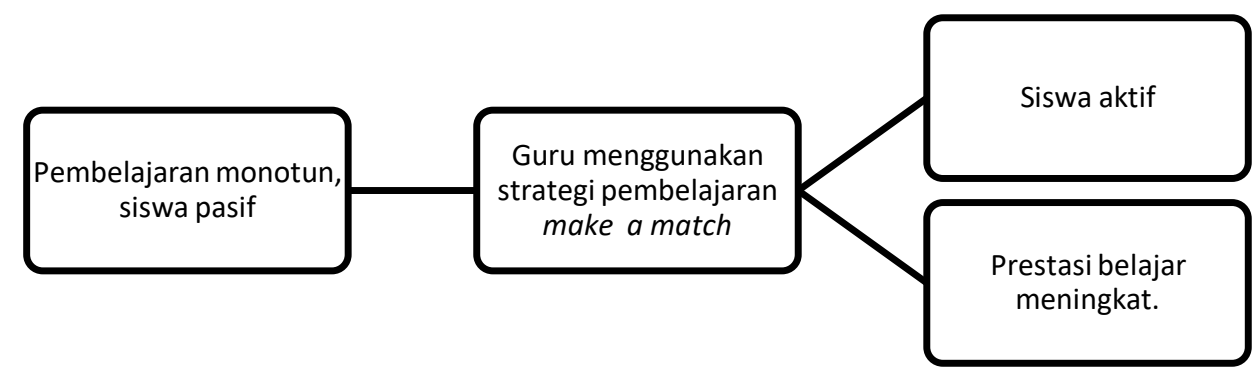

Gambar 1. Kerangka Berpikir

Dari kerangka berpikir tersebut dapat dikatakan bahwa saat proses pembelajaran guru berusaha untuk mengaktifkan semua siswa dengan mencari jawaban dari kartu yang dipegang. Siswa dituntut untuk segera menemukan pasangan dalam waktu yang ditentukan. Siswa berusaha berpikir, berkomunikasi, dengan temannya dan menemukan jawaban dari kartu soalnya. Akibatnya prestasi belajar matematika volume prisma segi tiga dan tabung meningkat.

\section{E. Hipotesis Tindakan}


Hipotesis tindakan dalam penelitian tindakan kelas ini adalah : "Penerapan model pembelajaran make a match (mencari pasangan) dapat meningkatkan prestasi belajar matematika volume prisma segi tiga dan tabung di kelas VI SD 2 Sukomulyo kecamatan Kaliwungu Selatan.

\section{F. Metode Penelitian}

Penelitian ini dilaksanakan di SDN 2 Sukomulyo UPTD Pendidikan Kecamatan Kaliwungu Selatan Kabupaten Kendal. Waktu penelitian 2 bulan. Subjek penelitian adalah siswa kelas VI SDN 2 Sukomulyo dengan jumlah siswa 20 terdiri 10 lak-laki dan 10 perempuan. Penelitian ini merupakan penelitian tindakan kelas yang mengacu pada model yang dikembangkan oleh Hopkins yang terdiri atas berbagai kegiatan yakni perencanaan (planning), tindakan (acting), observasi (observing), dan refleksi (reflecting). Keempat kegiatan tersebut dilaksanakan dalam 2 (dua) siklus penelitian. ${ }^{8}$

Teknik pengumpulan data menggunakan observasi dan tes hasil belajar siswa yang berisi 10 soal. Observasi dilakukan oleh teman sejawat untuk mengetahui aktivitas guru maupun siswa saat proses pembelajaran berlangsung. Observer dalam mengamati menggunakan lembar observasi yang berisi 5 indikator. Untuk guru menggunakan IPKG II. Observer mengamati dan mencatat kegiatan yang dilakukan guru sesuai dengan instrumen, sedang siswa pengamatan difokuskan pada keaktifan ketika mengikuti pembelajaran. Indikator keberhasilan dalam penelitian tindakan kelas ini adalah $80 \%$ siswa tuntas memperoleh nilai di atas 60 , dengan rata-rata nilai 70 .

Analisis data dalam penelitian tindakan kelas ini menggunakan analisis kuantitatif dan kualitatif. Data prestasi belajar diperoleh dari hasil evaluasi kemudian dikonversi dengan tabel kriteria. Hasil observasi dianalisis menggunakan teknik deskriptif kualitatif yang digambarkan dengan kata-kata atau kalimat yang dipisah-pisahkan sesuai dengan konteks permasalahan. Hasil perhitungan dikonversi dengan tabel kriteria deskriptif persentase, yang dikelompokkan dalam 5 (lima) kategori, yaitu sangat baik (86-100), baik (70-85), cukup (55-69), kurang (50-54), dan sangat kurang (0-49) (Murni, 2010: 52)

\footnotetext{
${ }^{8}$ Suharsini Arikunto, Penelitian Tindakan Kelas, (Jakarta: PT. Bumi Aksara, 2006)
} 


\section{G. Hasil Penelitian dan Pembahasan}

\section{Hasil Penelitian Siklus 1}

Berdasarkan hasil refleksi dan diskusi dengan teman sejawat bahwa pembelajaran pada siklus I ada kemajuan dan peningkatan siswa dalam pembelajaran dibandingkan dengan pembelajaran sebelumnya. Kemajuan hasil belajar dapat dilihat dari evaluasi yang diadakan setelah pembelajaran. Bahwa hasil belajar Matematika dalam kategori sangat baik, 4 anak (20\%) kategori baik, 7 anak (35\%) kategori cukup, 5 anak (25\%) kategori kurang, dan 2 anak (10,5\%) kategori sangat kurang. Bila dilihat dari rata-rata hasil belajar Matematika siswa sebesar 64,5 untuk hasil belajar matematika secara keseluruhan dalam kategori cukup.

Dari hasil analisis data perilaku siswa diketahui pada Siklus I pertemuan 1 dan 2 aktifitas siswa secara keseluruhan sudah menunjukkan peningkatan yaitu dalam kategori baik untuk menggambarkan kemajuan belajar siswa, maka penulis sertakan presentase tiap kategori pada siklus I dalam gambar grafik berikut:

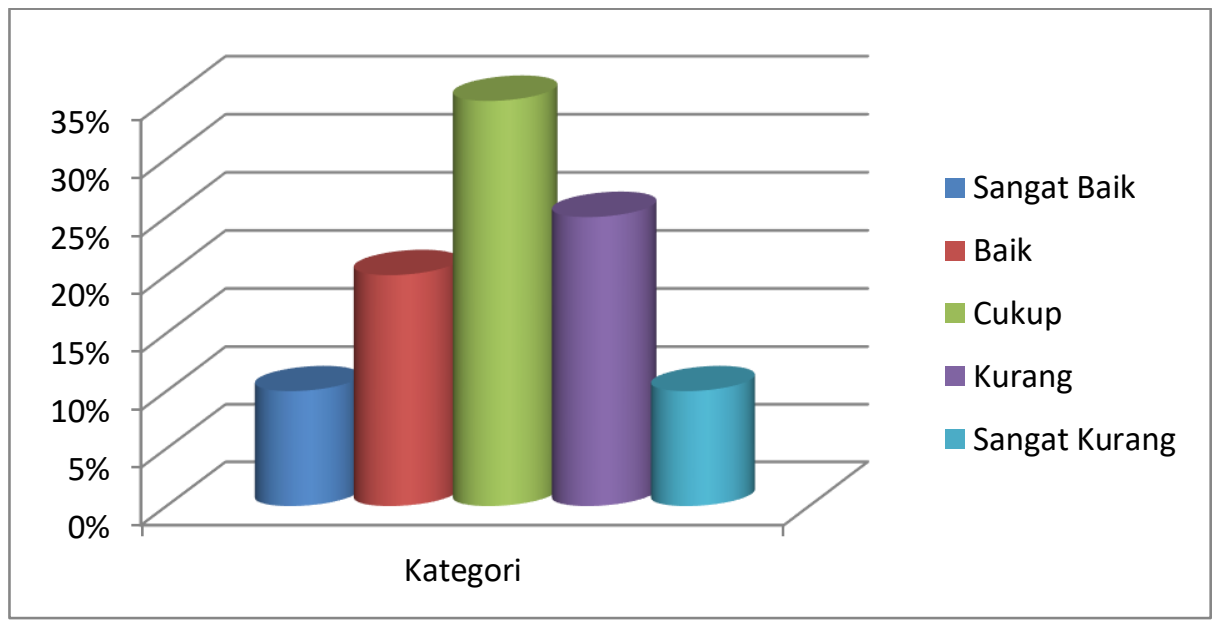

Gambar 2. Grafik Hasil belajar siklus I

Berdasarkan tabel di atas diketahui bahwa sebanyak 2 anak (10\%) memperoleh hasil belajar Matematika dalam kategori sangat baik, 4 anak (20\%) kategori baik, 7 anak (35\%) kategori cukup, 5 anak (25\%) kategori kurang, dan 2 anak (10,5\%) kategori sangat kurang. Bila dilihat dari ratarata hasil belajar Matematika siswa sebesar 64,5 maka dapat diketahui bahwa hasil belajar matematika secara keseluruhan dalam kategori cukup. Ketuntasan belajar secara keseluruhan 65\%. Rata-rata perolehan per 
indikator skor keaktifan siswa 82, 6 ini masuk dalam kategori baik.Selengkapnya dapat dilihat dalam grafik di bawah ini:

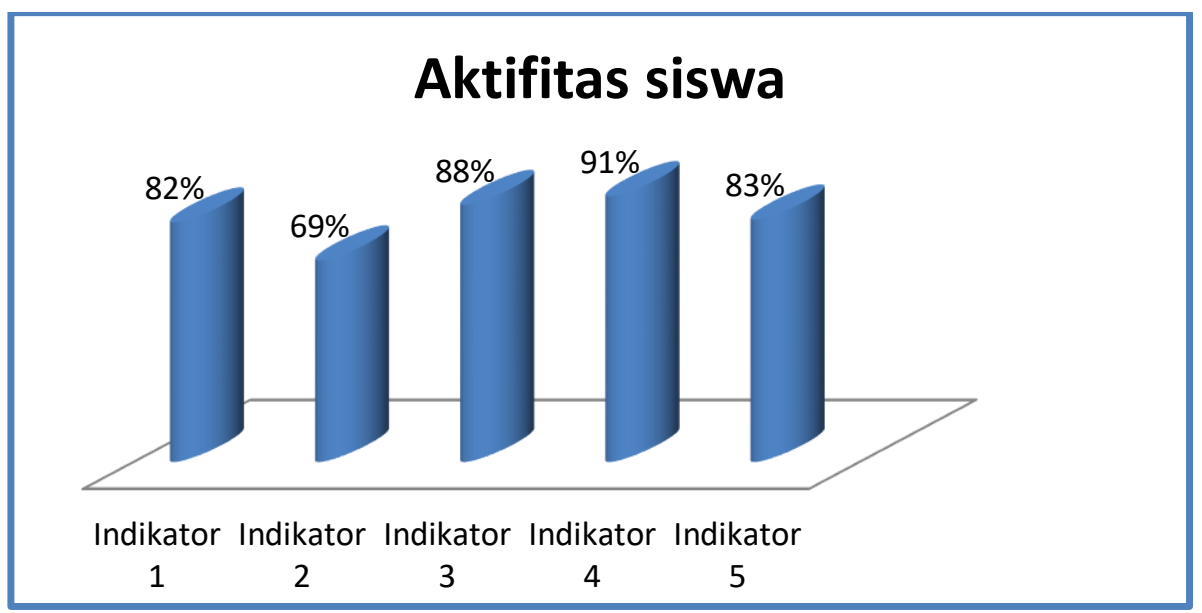

Gambar 3. Grafik Aktifitas siswa siklus I

Dari keseluruhan aktifitas siswa dalam pembelajaran Matematika volume prisma segi tiga dan tabung dengan strategi pembelajaran Make A Match di kelas VI SDN 2 Sukomulyo menunjukkan kemajuan yang baik. Perolehan nilai rata -rata per indikator dalam kategori baik. Dari tabel di atas dapat dilihat indikator 1 rata-rata dari seluruh siswa memperoleh skor 82 masuk kategori baik. Secara keseluruhan indikator memproleh kategori baik.

\section{Hasil Penelitian Siklus II}

Berdasarkan tabel dapat dilihat bahwa hasil belajar siswa yang memperoleh nilai $>70$ sebanyak 18 anak dengan persentase $90 \%$ kategori baik (60\% dan 30\%) kategori sangat baik, ada kenaikan dibanding siklus I (65\% ) masih ada 2 anak yang tidak tuntas. Bagi penulis hasil tersebut telah mencapai target penelitian. Rata- rata nilai keseluruhan sebesar 76 dalam kategori baik. Selengkapnya dapat dilihat pada grafik batang berikut: 


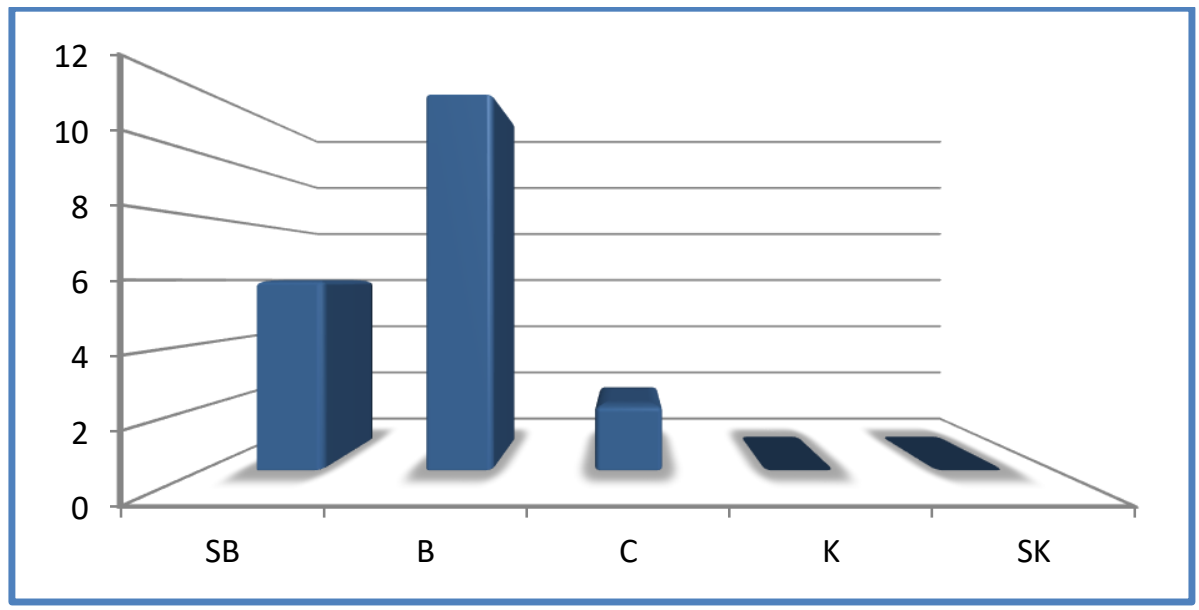

Gambar 4. Grafik Hasil belajar Matematika siklus II

Dari grafik di atas dapat dilihat bahwa hasil belajar matematika kategori baik 12 anak dan kategori sangat baik 6 anak. Pada siklus II ini siswa yang belum tuntas hanya 2 anak ( KKM 70 ). Siswa yang mendapat nilai > dari 70 sebesar 18 anak. Ketuntasan secara klasikal 90\% sangat baik. Pada siklus II target peneliti sudah tercapai. Berikut ini adalah hasil observasi siswa dalam kegiatan pembelajaran Matematika melalui strategi pembelajaran Make A Match dalam gambar grafik batang berikut:

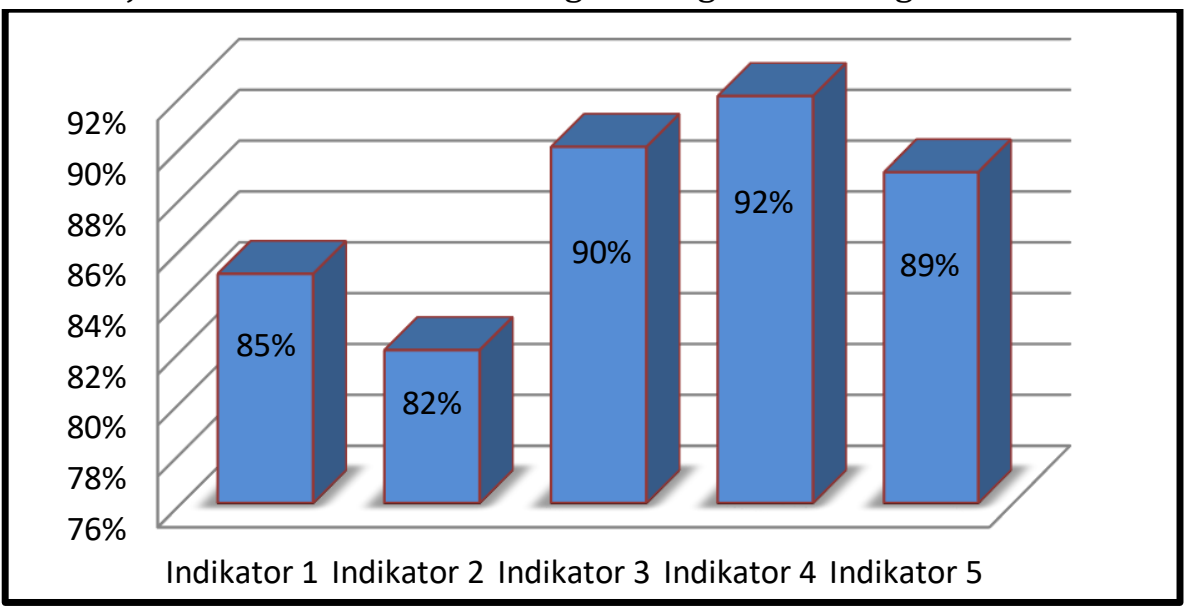

Gambar 5. Grafik Keaktifan siswa siklus II

Berdasarkan tabel di atas aktifitas siswa dalam pembelajaran Matematika volume prisma segi tiga dan tabung dengan strategi pembelajaran Make A Match dapat dikatakan ada peningkatan yang segnifikan. Hasil rata-rata per indikator $87,60 \%$ dalam kategori sangat 
baik. Indikator 4 (keaktifan siswa saat mencari pasangan) 92\% hanya 2 siswa dalam kategori cukup.Hasil observasi aktifitas guru saat pembelajaran yang berisi 10 indikator rata-rata 88\% kategori sangat baik.

\section{H. Pembahasan}

Siklus I hasil belajar matematika siswa menghitung volume prisma segi tiga dan tabung dengan strategi pembelajaran Make A Match menunjukkan kategori sangat baik 10\% (2 anak) dan 20\% (4 anak) kategori baik. dan 35\% (7 anak ) kategori cukup. Artinya di siklus I ini sudah ada kemajuan sebesar 13 anak telah tuntas dengan nilai di atas 70 . Lainnya (7 anak ) belum tuntas (KKM 70). Secara keseluruhan rata-rata 64,5 baru termasuk kategori cukup, sedangkan ketercapaian indikator ketuntasan 65\% dari keseluruhan siswa yang berjumlah 20 anak. Adapun aktifitas siswa di siklus I dapat dikatakan kemajuan yang segnifikan hanya pemahaman saat mencari pasangan masih kurang berjalan lancar. Ratarata perolehan per indikator skor keaktifan siswa 82, 6 ini masuk dalam kategori baik.

Pada siklus II hasil evaluasi belajar matematika volume tabung yang memperoleh nilai $>70$ adalah 18 anak atau sebesar 90\% kategori baik 60\% ( 12 anak) dan (6 anak) atau 30\% kategori sangat baik, 2 anak dalam kategori cukup. Bagi penulis hasil tersebut telah mencapai target penelitan. Rata- rata nilai keseluruhan adalah 76 dalam kategori baik. Pada saat siswa mengerjakan soal kebanyakan mencari volume tabung dengan mencari pasangan memakan waktu lama dibanding pada saat siklus I (yang hanya menghafal rumus dan mencari volume prisma segi tiga). Untuk membandingkan peningkatan prestasi siswa dan keaktifan siswa dalam proses pembelajarani tiap siklus tersaji dalam grafik berikut:

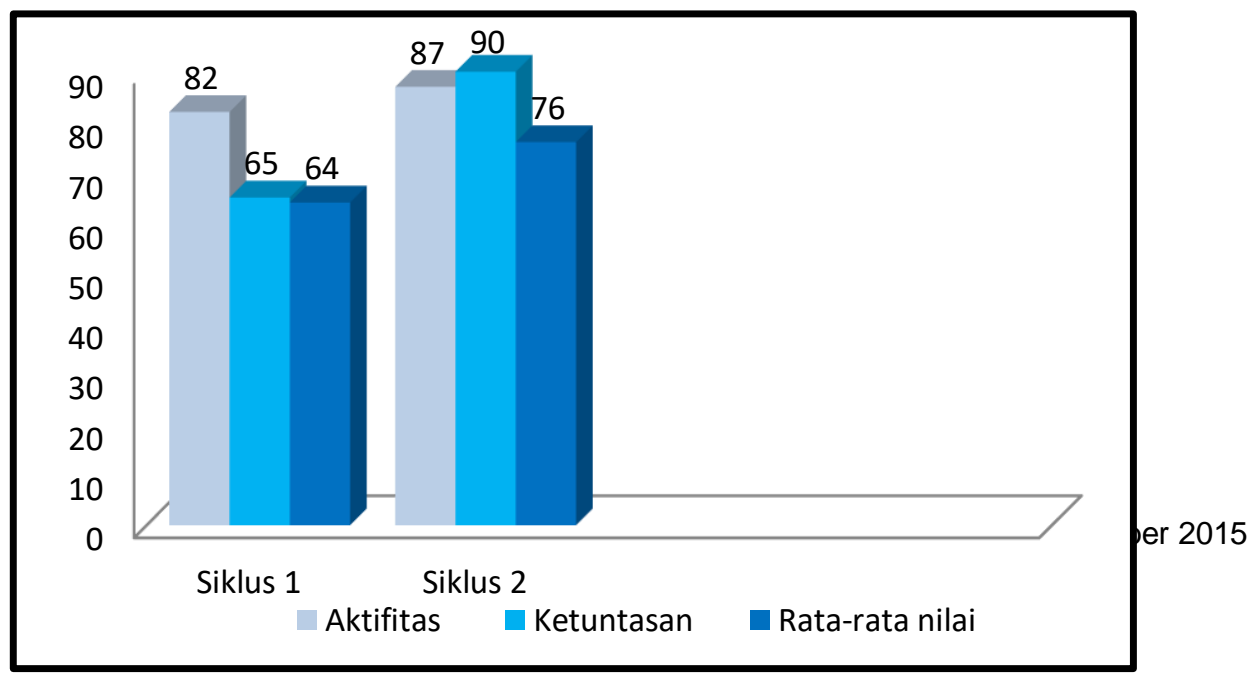


Grafik 6. Perbandingan hasil penelitian Siklus I dan Siklus I

Pada siklus II siswa rata-rata skor keaktifan belajar siswa kelas VI SDN 2 Sukomulyo dalam pembelajaran Matematika yang menggunakan strategi pembelajaran sebesar 82,6 termasuk kategori baik. Selain observasi keaktifan belajar siswa, juga dilakukan observasi terhadap proses pembelajaran yang dilakukan guru. Observasi guru dilakukan dengan menggunakan Instrumen Penilaian Kinerja Guru (IPKG). Berdasarkan hasil IPKG 2 tentang pelaksanaan pembelajaran diperoleh data rata-rata skor $88 \%$ termasuk kategori sangat baik.

\section{Simpulan}

Berdasarkan hasil penelitian tindakan kelas selama 2 siklus dapat disimpulkan bahwa terdapat peningkatan prestasi belajar siswa melalui strategi pembelajaran Make A Match dalam mata pelajaran matematika menghitung volume prisma segi tiga dan tabung kelas VI tahun 2012/2013. Hal tersebut ditunjukkan dengan hasil Siklus I rata-rata prestasi belajar siswa 64,5 naik menjadi 76 di siklus II.Indikator ketuntasan kelas sebesar $65 \%$ menjadi $90 \%$ pada kategori sangat baik. Keaktifan siswa pada siklus I rata-rata 82 pada siklus II menjadi 86. 


\section{DAFTAR PUSTAKA}

Hamalik, Oemar, Proses Belajar Mengajar, Jakarta: PT Bumi Aksara, 2009

Nasukha, Penggunaan Media Sempoa dalam Pembelajaran Matematika Siswa Kelas IV SD $N$ Gondang I Kecamatan Nawangan Pacitan Tahun Pelajaran 2007/2008, Skripsi, Universitas Sebelas Maret, 2008

Rejeki, Sri, Penerapan Pembelajaran Model Make A Match Pada Mata Pelajaran IPA Untuk Meningkatkan Hasil Belajar Siswa Kelas V SDN 02 Sengonwetan Semester 2 Th 2010/2011, Dalam repository.library. uksw.edu/../T1_292008013_Daftar Diunduh 21 September 2013, 2009

Rianarwati, Dwi, Penggunaan Media Gambar Dalam Pembelajaran Untuk Meningkatkan Prestasi Belajar Pengetahuan Sosial Kelas IV SD Mangun Baru Wates Kulon Progo. Skripsi. UNY, 2006

Rosanto, Penerapan Model Make A Match Pada Mata Pelajaran IPS Tentang Keadaan Alam Indonesia Untuk Meningkatkan Hasil Belajar Siswa Kelas V SDN 02 Semanggi Kecamatan Jepon Kabupaten Blora, repository.library.uksw.edu/.../T1_292008231_BAB\%. Diunduh tanggal 21 September 2013, 2009

Soedjadi, R Kiat Pendidikan Matematika di Indonesia (Konstatasi Keadaan Masa Kini Menuju Harapan Masa Depan, Jakarta: Ditjen Dikti Depdikbud, 1999

Zaini, Hisyam dkk, Strategi Pembelajaran Aktif, Yogyakarta: PT Insan Madani Islamic Publisher, 2008 